past 18 months, notes Fred Dylla, executive director of the American Institute of Physics, a publisher based in College Park, Maryland.

It will probably be a year or two before any policies are implemented, says Catherine Woteki, chief scientist at the US Department of Agriculture. Agencies might model their plans on the NIH approach, in which a government-funded repository, PubMed Central, is used to house the free research. "There's no sense in reinventing the wheel," says Woteki.

But Dylla suggests that the full text of papers could reside on publishers' websites, with agencies just providing links. The memo specifically encourages publicprivate collaborations, asks agencies not to duplicate existing mechanisms and requests that resources be found from existing budgets. These are hints, Dylla says, that the OSTP does not want to extend the PubMed Central approach. Some publishers resent that repository, which they see as deflecting attention from their own web pages.

The embargo time before papers are free could vary by discipline and journal, although agencies will have to justify any departure from the 12-month standard. In Europe, embargo times permitted in prospective public-access policies vary from 6 to 24 months. And just a week before the White House announcement, a bipartisan bill was introduced into Congress that would mandate a 6-month embargo for all.

But Michael Eisen, a biologist and openaccess advocate at the University of California, Berkeley, says that he is disappointed. "They had an opportunity to do something dramatically important, and instead they recycled a 5-year-old policy and went to great lengths to say that embargoes are critical for maintaining the publishing industry," Eisen says. He would rather that research be made free immediately.

That is the approach being taken in the United Kingdom, where science minister David Willetts has championed a move to a system in which work is immediately free to read. The UK funding agencies plan to finance this 'gold' open-access route by diverting some $1 \%$ of the national research budget, and requiring that authors or their institutions use it to pay publishers up-front to make work public. That policy will start to take effect from 1 April, but will ramp up slowly over five years: only $45 \%$ of research will be immediately free to read this year.

The United Kingdom had hoped to jolt other governments into following its lead. "We maintain our belief that the gold route is the best means of promoting openness and collaboration," says Willetts. But so far, researchers in the United States and the rest of Europe are not obliged to use science funds to make their work free immediately. SEE EDITORIAL P.401

\title{
Circular RNAs throw genetics for a loop
}

\section{RNA 'sponges' mop up sequences that curb gene expression.}

\section{BY HEIDI LEDFORD}

$\mathrm{B}$ ehold the latest curio in the cabinet of RNA oddities: naturally occurring circular RNA molecules that influence gene expression.

At least some of the loops, described in two papers published this week by Nature ${ }^{1,2}$, act as molecular 'sponges', binding to and blocking tiny gene modulators called microRNAs. But the researchers suspect that the circular RNAs have many other functions. The molecules comprise "a hidden, parallel universe" of unexplored RNAs, says Nikolaus Rajewsky, the lead author of one of the studies and a systems biologist at the Max Delbrück Center for Molecular Medicine in Berlin.

The discovery is yet another a reminder that RNA is much more than a mundane messenger between DNA and the proteins it encodes. The past two decades have seen the discovery of a host of nonconformist RNAs. Some were unexpectedly short or surprisingly long, and some flouted orthodoxy by blocking other RNA strands from being translated into protein. But almost all were linear. The few accounts of circular RNAs in plants and animals were generally dismissed as genetic accidents or experimental artefacts, says Erik Sontheimer, a molecular biologist at Northwestern University in Evanston, Illinois.

Instead, the predominance of linear RNAs may have been the artefact. Typical RNAsequencing methods isolate only those molecules with characteristic molecular 'tails'. With their ends joined together, round RNAs lack those tails, so have generally been overlooked.

But advances in sequencing have allowed biologists to accumulate large data sets of RNA sequences, including some from RNA without tails. Last year, Julia Salzman, a molecular biologist at Stanford University School of Medicine in California, and her colleagues sent the first missive from the circular universe. They reported finding a plethora of circular human RNAs while searching for RNA molecules that conventional methods might have missed ${ }^{3}$. And when Rajewsky and his colleagues mined databases for circular RNA molecules, they found thousands in nematode worms, mice and humans.

"It's yet another terrific example of an important RNA that has flown under the radar," says Sontheimer. "You just wonder when these surprises are going to stop."

Rajewsky and his colleagues, and a second, independent team ${ }^{2}$ led by Thomas Hansen and Jørgen Kjems of Aarhus University in Denmark, focused on a circular behemoth, some 1,500 nucleotides around, that is expressed in the brains of mice and humans. They found that it contains about 70 binding sites for a microRNA called miR-7. MicroRNAs are short fragments of RNA that can block gene expression by binding to and preventing the translation of messenger RNAs. MiR-7 targets have been linked to cancer and Parkinson's disease.

Hansen's team found that expression of the circular RNA blocked the blockers. The activity of miR-7 was suppressed, and the expres-

$\begin{array}{ll}\text { "Youjust } & \text { sion of miR-7's target } \\ \text { wonder when } & \text { genes increased, pre- } \\ \text { these surprises } & \text { RNA circle was cap- } \\ \text { are going to } & \text { turing and inactivat- } \\ \text { stop." } & \text { ing miR-7. Rajewsky's } \\ & \text { team showed that }\end{array}$
expressing the circular RNA or deleting miR-7 in zebrafish altered their brain development.

Circular RNAs could also be sponges for microRNA from outside the cell, notes Rajewsky. Some have possible binding sites for viral microRNAs, which can subvert immune responses. Rajewsky hypothesizes that circular RNA could even interact with RNA-binding proteins. Salzman agrees. "They are so abundant, there are probably a multitude of functional roles," she says.

So what other shapes might RNAs take? "I can't think of another form we might have missed," laughs Phillip Sharp, a molecular biologist at the Massachusetts Institute of Technology in Cambridge. "But you know somebody will find one." -

1. Memczak, S. et al. Nature http://dx.doi. org/10.1038/nature11928 (2013)

2. Hansen, T. B. et al. Nature http://dx.doi. org/10.1038/nature11993 (2013).

3. Salzman, J., Gawad, C., Wang, P. L., Lacayo, N. \& Brown, P. O. PLoS ONE 7, e30733 (2012).

\section{CORRECTION}

The News story 'Dark-matter hunt gets deep' (Nature 494, 291-292; 2013) wrongly gave the amount of usable xenon at PandaX as $25 \mathrm{~kg}$ instead of $120 \mathrm{~kg}$. 